\title{
INTEGRATING SUSTAINABLE CONSTRUCTION PRINCIPLES INTO CURRICULUM DESIGN FOR BUILT ENVIRONMENT PROFESSIONAL PROGRAMS IN NIGERIA
}

\author{
[Mustapha Yakubu ${ }^{1}$, Bishir Isah M. ${ }^{2}$, Abdullahi Ahmed B. ${ }^{3}$ ]
}

\begin{abstract}
This paper presents the findings of a research which sought to investigate the readiness to Integrate Sustainable construction Principles into Curriculum Design for Built Environment Professional programs in the Nigerian Universities. Developing the knowledge and understanding that construction professionals acquire of sustainable construction practice leads to considerable improvement in the environmental performance of the construction sector. Integrating sustainable environmental issues within the built environment education curricula provide the basis of this research. An integration of sustainable development principles into the universities built environment professional programmes are carried out with a view of finding solutions to the key issues identified.

The perspectives of academia have been assessed and findings tested for validity through the analysis of primary quantitative data that has been collected. The secondary data generated has shown that there are significant differences in the approach to curriculum design within the built environment professional programmes, and this reveals that there is no 'best practice' that is clearly identifiable. Sequel to the above, this research reveals that engaging all stakeholders would be a useful component of built environment curriculum development, and that the curriculum be negotiated with interested parties. These parties have been identified as academia, government, construction industry and built environment professionals.
\end{abstract}

Keywords: Built Environment, Curriculum Development, Sustainable Construction, Sustainable development

\section{INTRODUCTION}

The sustainable development is universal issue that has portrayed the attention of world leaders through a programme led by the United Nations (UN). Although sustainable development is not merely about environmental issues, but concern for the environment has been the driving force behind the global attention it is receiving. Sustainability issue is characterised by unanimous agreement at policy level and hampered by disagreement on putting policy into practice (Carter \& Fortune, 2008). However The concept of Sustainable Development relate to every aspect human activity, comprising the economic, social, and environmentally biased issues, which are frequently in conflict (Carter \& Fortune, 2008)

Sustainable development can be defined as development that meets the needs of the present generation without compromising the ability of potential generations to meet their needs (Bruntland

Mustapha.Yakubu, Faculty of Science, Technology, Engineering and Mathematics at University of Malaya-Wales

B. Isah, M,. is with Department of Quantity Surveying, Federal Polytechnic Kazaure, Jigawa State, Nigeria

Abdullahi Ahmed Baba; Faculty of Engineering, University Technology Petronas, Malaysia construction sector. Improving the knowledge and understanding that construction professionals acquire for sustainable construction practice leads to considerable improvements in the environmental performance of the industry. According SDEP (1999) argues that if sustainable development is the responsibility of everyone, then Education for Sustainability 'needs to pervade every aspect of life. It evidently states that education is central for promoting sustainable development' and that 'countries should stimulate educational establishments in all sectors, especially the tertiary sector, to contribute more to awareness building (Agenda 21, 1999). 1987). Sustainable construction practice is considered as the application of sustainable practices to the activities of the

\section{Literature Reviews}

\section{A. Theoretical concept of Sustainable Development Principles}

The concept of sustainable development is highly accepted at many levels of government worldwide (Elliot, 2009). The Rio Summit in 1992 developed and certified the concept of sustainable development. This has led to a wider understanding and has developed the need to make decisions based on the 'triple bottom line' (TBL) of environmental protection, social justice and economic feasibility (Sayce, 2008). Elliot (2009) explores that it would be very difficult to have Sustainable solutions without balancing out all the three elements. Referring to (Figure 1.0), a sustainable solution would aim to satisfy all three elements and position somewhere in the centre of the diagram. According to Sayce (2008) explores that the three elements of sustainability referred to as the 'Triple Bottom Line', an expression commonly used in a commercial sense where traditional accounting is expanded to take the three "P"s into account, i.e. people, planet and profit. Within the triple bottom line, further distinctions can be drawn and these are shown diagrammatically in (Figure 1.0.)

The Construction Best Practice Programme (CBPP) acknowledges that these links between environmental, social and economic feasibility and terms their inter-relationship to the triple bottom line. However, these Links to construction have gradually become reinforced but have been related to the principle of sustainable development practice. Figure 1.0 the three elements of sustainability

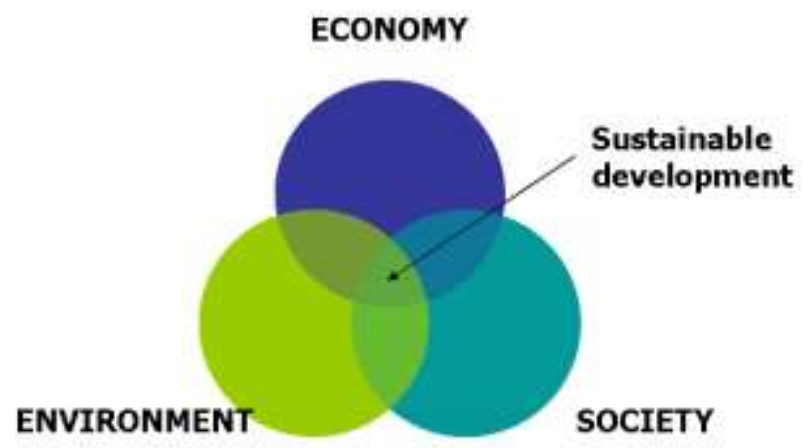

Figure 1.0 the three elements of sustainability. Adopted from (Sayce, 2008) 


\section{B. Education for sustainable Construction Practices}

Education has been identified as critical for promoting sustainable development practices and improving the capacity of the people to address environment and development issues and also critical for achieving environmental and ethical awareness, values and attitudes, skills and behaviour consistent with sustainable development and for effective public participation in indecision (Palmer, 1998) Education for sustainable construction should be incorporated in the built environment curriculum at all levels (WCED, 1987). Frien (2003) emphasises that the contents for sustainable development knowledge, skills, and attitudes needed are underplayed in current universities education curricular. However, the studies of environmental issues in the built environment programmes are typically within separate disciplines, with little concern for integrating sustainable development knowledge and skills into the field of built environment professional programmes (Fien, 2003).

\section{Role of Higher Education in Sustainable Development practice}

Higher education has a central role to play in achieving sustainable development within the field of built environment programmes. This is because sustainable development is fundamentally a process through which society to build their capacity to live better (Campus Earth Summit 1995). It is a process which everyone needs to participate in, but the involvement of higher education is particularly important because graduates potentially occupy the enormous majority of managerial and leadership positions in the future. Thus the role of higher education far outweighs the size of the sector in terms of its resources (Abubakar, 2005).

This role is recognised by many people in the higher education community and reflected by several international agreements between institutions to pursue sustainable development; the Kyoto Declaration on Sustainable Development issued by the International Association of Universities (1993); and the UNESCO World Declaration on Higher Education (1998). Many institutions of higher learning have been involved in drawing up these agreements. Furthermore, Blewitt \& Cullingford (2004) explores that Higher Education has crucial role to play in outlining an agenda for sustainable education and institutional change. The first three action plans of the Talloires Declaration are as follows; Increase awareness of environmentally sustainable development, Create an institutional culture of sustainability and Educate for environmentally responsible citizenship (Blewitt \& Cullingford, 2004).

\section{Research and Teaching for sustainable development issues}

In the world summit on sustainable development, Nath \& Hens (2005) emphasises the need to review the programmes and curricula of built environment programmes to address the challenges and opportunities of sustainable development research within the built environment programmes, which would focus on creating learning modules which integrate skills, knowledge, and attitudes. These views recognise that the role of higher education is broadly three-fold. Higher education has a role in helping students gain a new awareness of the world in which they live; an understanding of how complex economic, social and environmentally biased processes interact with each other; and a familiarity with perspectives on these issues from other societies and cultures.

It is essential that built environment professionals not only participate in the design of projects with low environmental impact, but equally, that they learn to conceive, promote and facilitate the kind of model changes seen as necessary to create a sustainable society (Graham2000). This can best achieved through better higher education. The level of modifications of these curricula were inadequate mostly due to the undergraduate backgrounds, nature of Higher Education, academic indifference and communication gap between professionals in academia and the industry (Ryan, 2003).

\section{E. The Curriculum Design for Sustainable Construction Development Practices}

Educational framework offers a key component of best practice for curriculum design, which includes integration as opposed to fragmentation, and a learning outcomes approach to curriculum design. Education for sustainable development is essential element in human capacity development. However, it has long been neglected as an area of development, it has been recognised that no development is possible without a functioning education system (Spranger, 1992). At the formal level of education, the responsibility for environmental education largely depends on schools, universities and other tertiary institutions (Palmer, 1998). At the universities level, education for sustainable environment was considered inadequate. The education for sustainable construction development practices are yet to be incorporated into Nigerian universities curriculum design.

The Nigerian policy on education was based on great many assumptions. This type of policy has clearly not been attained for more than twenty years after the implementation of the curriculum (Sambo, 2005). A comprehensive evaluation of the curriculum has not been undertaking to find out the reasons for the failure of the policy to achieve the desired objectives. Incorporating education for sustainable development creates a great amount of knowledge from which the educators could chose. The traditional forms of education must give ways to new concepts of education for sustainable development (Sambo, 2005). These global changes call for Nigerian educational programmes to integrate principle of sustainability in its curriculum redesigns. Aminu Kano (2002) emphasises that a review of curriculum to more environmentally friendly and sustainable construction practice in Nigerian Universities is critical.

\section{RESEARCH METHODOLOGY}

\section{A. Scope of research}

Within this research the origin of sustainability is examined from its beginning in sustainable development through to the education for a more sustainable construction practice. The environmental issues within the field of built environment programmes were examined to identify the extent of integrating sustainable development principles into the universities built environment programmes in Nigeria. The fundamental aim of this research project is to examine the level of integrating the principles of sustainable construction development into the built environment professional programmes and focusing on how environmental issues should be included into their curriculum design.

\section{B. 3.2 Data Collection Techniques}

In order to achieve the aim of the report, a multi-approach was adopted for data collection to integrate the strengths of each technique. In broad terms, questions fall into two types - openended questions and closed-ended questions. Both were used in carrying out this study. Open-ended questions were firstly adopted at pilot survey which later changed to close-ended questions for final phase of the research questionnaire. The length of the questionnaire was moderate comprising of 20 questions designed for both undergraduates and postgraduates and professional staffs within the built environment programmes. The questionnaires were administered among the group mentioned.

The pilot survey focused toward the collecting of qualitative data relating to sustainable construction development from the entire population. This approach was chosen to increase the validity and scope of the data collection techniques, depth and knowledge of the collected data. A pre-testing questionnaire was administered to construction experts within the built environment identified to 
justify responses for validation purposes. Survey Refined written and printed questionnaires comprising a series of structured questions were administered directly to a number of construction experts with various backgrounds identified to obtain data for the study. The purpose of the process was to gain information about construction expert's point of view regarding issues of sustainability in building projects. The research commenced by reviewing and analyzing the relevant literature review on sustainable development issues.

\section{SURVEYS}

Further, face to face interviews were conducted with professionals in the built environment within the academia. The purpose of the interviews was to discuss and establish their views regarding incorporating sustainability in their curriculum. The questionnaire targeted three specific groups of respondents who provide innovative information for the study; the samples are undergraduate, post graduate students and professional staff of the universities chosen who were believed to be involved in the education for sustainable construction development within their programmes. This led to the use of stratified random sampling. Data were randomly selected from each group and later analysed. The questionnaires were sent to 160 professionals from academia, post graduate and undergraduate students. These professionals were involved in construction project management for a considerable number of years. The respondents were asked to rate based on their professional experience each of the issues presented using a range from "Strongly disagree" or on a "Strongly agree" 5 point Likert scale.

\section{A. Background of respondents}

160 questionnaires were sent to professionals who were involved in the sustainable construction management practices within the university environment in Nigeria. They included 65 undergraduate, 57 postgraduate/professionals. 122 responses were received, after checking through the completed questionnaires, 120 questionnaires were found to be suitable for data analysis. This yielded a response rate of about $75 \%$. Table 4.0 shows the details of the responses.

\begin{tabular}{|l|l|l|}
\hline & \multicolumn{2}{|l|}{ Response rate } \\
\hline Questionnaire & Frequency & Percentage \\
\hline undergraduate Students & 65 & $41 \%$ \\
\hline $\begin{array}{l}\text { Postgraduate student/ } \\
\text { professional Staff }\end{array}$ & 57 & $36 \%$ \\
\hline not received & 38 & $24 \%$ \\
\hline & 160 & $100 \%$ \\
\hline
\end{tabular}

TABLE 4.0 Response rate

\section{DATA PRESENTATION}

Out of 160 responses received, after checking through the completed questionnaires, 122 questionnaires were found to be suitable for data analysis. This yielded a response rate of about $75 \%$. The data collected from the 160 questionnaires was then analyzed statistically.

\section{A. Data for the curriculum design of sustainable development contents}

\begin{tabular}{|c|c|c|}
\hline $\begin{array}{c}\text { Responses } \\
\text { rate }\end{array}$ & Frequency & percentage \\
\hline Yes & 15 & $12 \%$ \\
\hline No & 107 & $88 \%$ \\
\hline Total & 122 & $100 \%$ \\
\hline
\end{tabular}

Table 4.12 Do you experience any modification in your programme curriculum?

\section{B. Data for integrating sustainable construction practice}

\begin{tabular}{|c|c|c|c|c|}
\hline Response & $\begin{array}{c}\text { Under } \\
\text { graduate } \\
\text { frequency }\end{array}$ & percentage & $\begin{array}{c}\text { post } \\
\text { graduate } \\
\text { frequenc } \\
\text { y }\end{array}$ & percentage \\
\hline $\begin{array}{c}\text { Strongly } \\
\text { disagree }\end{array}$ & 0 & & 0 & 0 \\
\hline Disagree & 3 & $5 \%$ & 6 & $11 \%$ \\
\hline Neither & 2 & $3 \%$ & 0 & $0 \%$ \\
\hline Agree & 37 & $57 \%$ & 19 & $33 \%$ \\
\hline $\begin{array}{c}\text { Strongly } \\
\text { agree }\end{array}$ & 23 & $35 \%$ & 32 & $56 \%$ \\
\hline & 65 & $100 \%$ & 57 & $100 \%$ \\
\hline
\end{tabular}

Table 4.13 how do you agree that the construction industry needs to change from traditional method towards more sustainable approaches?

Table 4.14 "Sustainable construction principle can be regarded as an integration of social sustainability, biophysical sustainability, economic sustainability and technical sustainability" how do agree that this concept was included in your programme curriculum?

\begin{tabular}{|l|c|c|}
\hline Responses rate & Frequency & percentage \\
\hline Strongly disagree & & \\
& 71 & $58 \%$ \\
\hline Disagree & 34 & $28 \%$ \\
\hline Neither & 12 & $10 \%$ \\
\hline Agree & 5 & $4 \%$ \\
\hline Strongly agree & 0 & $0 \%$ \\
\hline Total & 122 & $100 \%$ \\
\hline
\end{tabular}

Table 4.15 "Did your programmes have a sustainability framework and guidelines that can be incorporated in all construction process?"

\begin{tabular}{|c|c|c|}
\hline Responses rate & Frequency & percentage \\
\hline Yes & 17 & $14 \%$ \\
\hline No & 105 & $86 \%$ \\
\hline Total & 122 & $100 \%$ \\
\hline
\end{tabular}




\section{ANALYSIS OF RESULTS}

a) Analysis of Figure 4.11 "how do you relate your knowledge for sustainable built environment?"

In response to the above question, in Figure 4.11 there was a huge gab identified here. It shows that $94 \%$ of undergraduate studies gave general coverage of knowledge for sustainable development while it also shows that $86 \%$ contents for post graduate studies gave specific coverage of sustainable development. This view was well supported in literature which clearly highlighted that the undergraduate built environment programmes regarded as broad and balanced; while postgraduate programmes were considered as focused and specialized. Furthermore, this result reaffirms that their programme were considered less holistic (fig. 4.1).

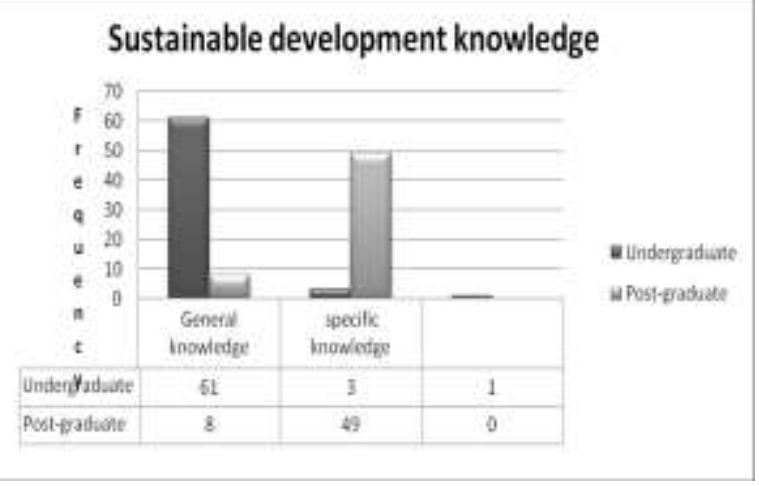

(Figure 4.1 sustainable development knowledge)

b) Analysis of Table 4.12 "Do you experience any modification in your programme curriculum?"

The literature acknowledges that modification and integrating the sustainable development principles into curricula of built environment programmes is necessary. Respondents were asked if they have experienced any changes in their curriculum. Table 4.12 set out the results which clearly indicates strong consensus (88\%) that they have not witnessed any serious reviews in their programmes curriculum. These views were strongly supported in the literature which proposes that adequate modifications in curriculum design for built environment programmes were not being made mostly due to the nature of Higher Education, undergraduate backgrounds, academic indifference and lack of communication between industry and academia (Leal Filho 2000).

c) Analysis of Table 4.13 "how do you agree that the construction industry needs to change from traditional method towards more sustainable approaches?"

In response to the above question in table 4.13, it shows that a total of $57-92 \%$ respondents have strong consensus that construction industry need to change from traditional perspectives towards more sustainable approaches. This is strongly supported in the literature which proposes that

d) Analysis of Table 4.14 "Sustainable construction principle can be regarded as an integration of social sustainability, biophysical sustainability, economic sustainability and technical sustainability" how do agree that this concept was included in your programme curriculum?

In response to the above question in table 4.14, it shows that a total of $58-86 \%$ respondents have strongly disagreed that the basic features sustainable construction principles were not comprehensively included into their programmes while only $4 \%$ of respondents incorporated the basic principle of sustainable construction practice into their built environment programmes. e) Analysis of Table 4.15 "Did your programmes have a sustainability framework and guidelines that can be incorporated in all construction process?"

In response to the above question in table 4.15, it shows that a total of $86 \%$ respondents have not incorporated any sustainable development framework to guides all their construction process. This analysis indicates that the framework for sustainable construction practice can be interpreted differently by different professionals within the built environment programmes. The result reveals that there is no best practice relating to curriculum designing for the built environment professional programmes. This is strongly supported in the literature which proposes that education framework offers a key component of best practice for curriculum design, which includes integration as opposed to fragmentation, and a good learning outcomes approach to curriculum design.

\section{CONCLUSION}

This report presented and analysed data that examine the level of integrating the principles of sustainable construction development principles into the built environment professional programmes and has highlighted the importance of education for sustainable development where data analysis revealed most of the respondents significantly agreed that their sustainability knowledge and competencies were knowledge related and it is highly significant to incorporate the principles of sustainable development into the built environment undergraduate programmes.

This research has explored that majority of respondents were predominantly biased toward environmental aspects of sustainable development, however, it further reveals that the core modules have no learning out comes that make specific reference to sustainable development issues. From the results discussed it can be noted that, must respondents do not have educational framework on sustainable construction practice but strive to achieve same in their programmes and the study revealed that construction industry should move towards more integrating the principle sustainable development.

It can also be concluded that, engaging all stakeholders in curriculum design would be a useful component of 'best practice' however, lack of involving all stakeholders in the curriculum design and inadequate reviews in curriculum design are the key factor that the respondents have seen as the constrain for effective integration of sustainable development principle into the built environment programmes. The data generated has revealed that there are significant discrepancies in the approach to curriculum design, and can be concluded that there is no 'best practice' identified yet.

It was soundly recognised that the principles of Sustainable construction integrated the key principles of sustainable development. However, the critical problems were recognised as that construction industries operate in a more traditional approach. The call for changes from these traditional practices towards a modern technique, which recognises the importance of innovation, training and research and adopt collaborative and sustainable approaches were identified (Myers, 2005). these could be attained through incorporating all supply-chain, engage all stakeholders, and establish an ethical and enhanced sustainability profile, and changes from linear to cyclic processes

The research has highlighted the importance of education for sustainable development and the analyses revealed that most of the respondents significantly agreed that their sustainability knowledge and competencies were knowledge related and it is highly significant to incorporate the principles of sustainable development into the built environment undergraduate programmes. 


\section{REFERENCES}

Abubakar, L. (2005). An Investigation into and Appraisal of Sustainable Construction Practices in Universities' Building Programmes. unplublished thesis submitted to .

Addis, B., \& Talbot, R. (2001). Sustainable construction procurement: A guide to delivering environmentally responsible projects. London: CIRIA.

Aminu Kano, H. (2002). Environmental Management in Nigeria with regards to Building Construction Projects. Millennium Conference "Building in the 21st Century" (pp. 1-62). Zaria: Department of Building ABU Zaria-Nigeria.

Anselm, A. J. (2009). China's Environment and Challenges of Sustainable Environment, a test case forSustainability Sttudy for theNigerian Sustainable Environment Goals. 1st National Conference on Sustainable Environment in Nigeria. Bauchi: School of Environmental Technology ATBU Bauchi.

Blewitt, J., \& Cullingford, C. (2004). The Sustainability Curriculum:The Challenge in Higher Education. London: Earthscan.

Bossink, B. A. (2002). A Dutch public-private strategy for innovation in sustainable construction. Construction Management and Economics , 20, 633-642.

Cole, J. R. (1998). Emerging trends in building environmental assessment methods. Building research and information , 26 (1), 3 16.

Manoliadis. (2006). Sustainable construction and drivers of change in Greece: a Delphi study. Construction Management and Economics , 24, 113-120.

Matar, M. M., Georgy, M. E., \& Ibrahim, M. E. (2008, March). Sustainable construction management: introduction of the operational context space (OCS). Construction Management and Economics , 261-275.

Myers, D. (2005). A review of construction companies' attitudes to sustainability. Construction Management and Economics , 23, 781785 .

Myers, D. (2005, October). A review of construction companies' attitudes to sustainability. Construction Management and Economics , 781-785.

Palmer, J. A. (1998). Environmental education in the 21st century: theory, practice,progress and promise. London: Routledge.

Plessis, C. (2007). A strategic framework for sustainable construction in developing countries. Construction Management and Economics , 25, 65-76.

Ryan, L. (2003). Towards Environmental Education for Sustainable Development: The Contributions of NGOs in the AsiaPacific Region. International Review for Environmental Strategies , 4 (1), 59-73.

Sambo, A. A. (2005). Research Methods in Education. Ibadan: Stirling-Horden Publishers (Nig) .

WCED. (1987). Our common future. oxford: Oxford University Press.
Yakubu, M. (2010). Unpublished thesis: An Integration of Sustainable Construction Principles into the Built Environment professional Pragrammes in Nigeria. Heriot Watt University UK. 